\title{
The Effect of Red Dragon Drinking Fruit (Hylocereus Costaricensis) Against Fetal Growth in Pregnant Cigarette Rats Exposed to Cigarette Smoke (100\%, 75\% And 50\% Dragon Fruit Juice Concentration)
}

\author{
Ari Widyaningsih* and Wahyu Kristiningrum \\ Universitas Ngudi Waluyo, Jl Gedongsongo, Candirejo, Ungaran Barat, Kab Semarang, Indonesia
}

Submission: April 11, 2018; Published: April 19, 2018

*Corresponding author: Ari Widyaningsih, Universitas Ngudi Waluyo, Jl Gedongsongo, Candirejo, Ungaran Barat, Kab Semarang, Indonesia; Email: widyaningsihari@ymail.com

\begin{abstract}
Cigarettes are one of the environmental factors that can cause birth defects. Smoking habits in pregnant women can cause spontaneous abortion and prenatal fetal death. To counteract the free radicals generated by cigarette smoke, the body needs antioxidants that can help protect the body from free radical attack. In addition to vitamin C, flavonoids are known to have a very useful antioxidant effect, one of the flavonoids found in red dragon fruit (Hylocereus costaricensis) is quercetin. The purpose of this study to determine the effect of red dragon fruit juice on the effects of exposure to cigarette smoke in pregnant rats. The study design was purely experimental with post test only control group design with Completely Randomized Design (RAL) consisting of one 1 group of positive control using vitamin C dose $0,4 \mathrm{ml}, 1$ group of dragon fruit juice with concentration $100 \%$ dose $2 \mathrm{ml} / 200 \mathrm{gr}, 1$ group of dragon fruit juice with concentration $75 \%$ dose $2 \mathrm{ml} / 200 \mathrm{gr}, 1$ group of dragon fruit juice with concentration $50 \%$ dose $2 \mathrm{ml} / 200 \mathrm{gr}$. The results showed that the group of red dragon fruit (Hylocereus costaricensis) dose of $2 \mathrm{ml} / 20 \mathrm{grBB}$ with 100\% concentration had the effect seen from (Average Weight Gain Everyday) PKBP mother mouse and fetal body weight of mice exposed to cigarette smoke comparable with vitamin C. Dragon fruit can prevent damage to organs and abortus and can help the growth of the fetus in pregnant mice exposed to cigarette smoke.
\end{abstract}

Keywords: Dragon fruit; Cigarette smoke; Vitamin C

\section{Background}

Percentage prevalence of male smokers is 56,7\% far bigger than female smoker that is $1,8 \%$. There is a large gap between the number of adult male smokers and female smokers who smoke every day OECD [1]. Smoking habits in Indonesia and several other developing countries continue to increase. Smokers in Indonesia amount to $75 \%$, as many as $60 \%$ of the male population and $15 \%$ of women GATS [2]. Exposure to cigarette smoke is very worrying for some social groups including pregnant women. Pregnant women are usually exposed to secondhand smoke by their partners or co workers. Active and passive smokers during pregnancy are conducive to pregnancy disruption Wdowiak and Wiktor [3]. Yuliana [4] in a paper said that a study conducted by the British Medical Association's Cobob Control Resource Center showed that mothers who smoked during pregnancy had a risk of delivering low birth weight infants 1.5 to 9.9 times compared with birth weight babies of mothers who do not smoke. The body needs antioxidants that can help protect the body from free radical attacks by inhibiting the negative effects of compounds contained in cigarettes. Some certain plants also have a very useful antioxidant effect, one of which is the red dragon fruit (Hylocereus costaricensis). Red dragon fruit antioxidants are higher than white dragon fruit because of the red pigment (anthocyanin). Flavonoids contained in dragon fruit include quercetin, kaempferol, and isorhamnetin Panjuantiningrum [5]. The purpose of this study to determine the effect of red dragon fruit juice on the effects of exposure to cigarette smoke in pregnant rats. Based on research Febrianti [6] on the Influence of Apple Fruit Juice (Malus sylvestris mill) Varieties of Rome Beauty In Smoking Rats Exposed Smoke Cigarettes obtained results that the apple juice treatment group (Malus sylvestris mill) varieties Rome beauty dose 1.67g / 20g BB and 2.5g / 20g BB has the effect seen from PKBP mice and fetal body weight of mice exposed to cigarette smoke comparable with vitamin E dose 130IU. 


\section{Research Methodology}

\section{Tools and Materials}

Tools: juicer, juice filter, beaker glass, animal cage, mouse scales, scalpel, tweezers, scissors, needles, gastric sonde, $1 \mathrm{ml}$ syringe, $3 \mathrm{ml}$ and $5 \mathrm{ml}$.

Ingredients: dragon fruit (Hylocereus costaricensis), standard feed of BR-2, cigarette smoke obtained from cigarette X, pregnant mice swiss webster strain 2-3 months old with weight 20-30g, vitamin $\mathrm{C}$, chloroform.

\section{Research Procedure}

Mating mice by means of adult and ready-mixed rats has a weight of 28 grams of male rats and 20-30 gram female rats. Female rats mated to male rats naturally by unifying female rats and male rats in one cage with a ratio of 2 females and 1 male at 17.00WIB. The next morning observations were made in the vaginal area, observed for a vaginal plug (copulatory plug or vagina plug). Making cigarette smoke by using a syringe that ends with a cigarette burned, exposed to 1 cigarette / day. Every 3 rats were placed in boxes of $30 \times 15 \times 15 \mathrm{~cm}$. Making dragon fruit juice by dragon fruit is still fresh taken and washed until clean with running water to remove dirt. Dragon fruit fruit weighed as much as 100gr then cut into small pieces, then put into juicer to be taken sari. Dragon fruit juice inserted into beaker glass. Based on the orientation obtained dragon fruit juice in 100 grams of $80 \mathrm{ml}$ with a concentration of $100 \%$ (dose $2 \mathrm{mg} / 20 \mathrm{gBB}$ rat). This study used 25 pregnant mouse rats. The random animals were divided into 4 groups:

a. The positive control group (K2) was given a vitamin C dose of $0.4 \mathrm{ml} / \mathrm{g} /$ day / day from the 5 th to 15 th of pregnancy and was exposed to cigarette smoke.

b. The first treatment group (P1) was given dragon fruit juice with a concentration of $100 \%$ doses of $2 \mathrm{ml} / 20 \mathrm{grBB}$ mice from 5-15 gestation pregnancy and was exposed to cigarette smoke.

c. The first treatment group (P2) was given dragon fruit juice with a concentration of $75 \%$ doses of $2 \mathrm{ml} / 20 \mathrm{grBB}$ of mice from 5-15 pregnancy days and was exposed to cigarette smoke.

d. The first treatment group (P3) was given dragon fruit juice with concentration of $50 \%$ dose $2 \mathrm{ml} / 20 \mathrm{grBB}$ of mice from 5-15 pregnancy days and given exposure to secondhand smoke.

e. The data were collected by measuring the mother's weight during pregnancy and examining the fetus. Examinations performed on the fetus include fetal weight, fetal number, disability, number of dead fetuses and fetal resorption.

\section{Preparation of Materials and Making Dragon Fruit Juice}

The dragon fruit is still freshly washed, then in juicer and accommodated sari. Dragon fruit juice inserted into beaker glass. The content of dragon fruit juice is $100 \%$, then made in
$2 \mathrm{ml} / 20 \mathrm{gBB}$ dose, to make $75 \%$ concentration using $75 \%$ juice ratio plus $25 \%$ water, and $50 \%$ concentration with $50 \%$ water ratio and $50 \%$ juice. The juicer method is chosen because it has several advantages, including ease in research and takes a short time, other than that the exertion is done by juicing process very quickly and perfectly so that minimize contact with oxygen and easy to apply in society Cempaka et al. [7].

\section{Mate and Grouping of Test Animal}

Female rats mated to male rats naturally by unifying female rats and male rats in a cage with a ratio of 4 females and 1 male. The purpose of mating the mice to control the possibility of nonpregnant mice, and ensuring the mice treated bunting starting day to 0 . Because it is feared if not married alone, the mice used may not be pregnant or the age of pregnancy rats instead of days 0 .

\section{Cigarette Smoke Production}

Cigarette smoke is used as a form of exposure to free radicals. The cigarette used is kretek type. The selection of Type X cigarettes is based on high levels of tar and nicotine compared to other types of cigarettes. Each rat was put into a box with a size of $30 \mathrm{x} 15 \mathrm{x}$ $15 \mathrm{~cm}$ and then on one side of the box was given a small hole then cigarette smoke was inserted using pumped syringe and exposed through a small hole in the box to 1 cigarette / day.

\section{PKBP Data}

In statistical analysis with Mann-Whitney method showed that dragon fruit juice dose $2 \mathrm{ml} / 20 \mathrm{grBB}$ with $100 \%$ concentration did not give significant difference (have equal ability) to increase PKBP mother mouse with positive control group given vitamin C.

\section{Fetus Weight Data}

In statistical analysis with Mann-Whitney method showed that dragon fruit juice dose $2 \mathrm{ml} / 20 \mathrm{grBB}$ with $100 \%$ concentration can give significant difference of fetal weight in negative control group and in positive control group given vitamin C. Meaning of dragon fruit juice treatment with dose of $2 \mathrm{ml} / 20 \mathrm{grBB}$ with $100 \%$ concentration, and positive control affect the fetus rat body weight.

\section{Number of Fetal Data}

From result of LSD test, it is seen that $\mathrm{p}$ value between negative group and positive control in rat number of fetus have influence (there is difference) because $p$ value $<0,05$. While between the other groups there is no difference (the effect is the same) normally mice produce a sufficient number of children that is 5-10 tail. So from the data obtained both the negative control, positive control and treatment group has the number of fetuses born still in the normal range. In this study also found the existence of morphological defects in the fetus. This is also found in the research conducted by Rahmadina [8] that the giving of tobacco water extracts can cause teratogenic effects on rat fetus. Thus, in this study no morphological defects were found because the levels of nicotine, carbon monoxide and other radical compounds found 
in cigarette smoke were smaller than tobacco water extracts. One of the chemicals in cigarette smoke that can affect implantation is nicotine. Provision of nicotine directly or indirectly can inhibit the process of cell division, inhibits the formation of blastocytes, and prevent the occurrence of implantation and even interfere with the entry of the embryo into the uterine cavity.

The number of normal fetal mice in a given birth of 5-10 heads so that in this study the average number of fetuses are still within the normal range in each group. This is because the number of fetuses can be affected by genetic factors, the size of each fetus varies and the presence of different genetic susceptibilities, and the ability of the embryo to implant. In addition, the administration of cigarette smoke is done in the organogenesis phase (after the implantation phase) so as not to affect the fetus during implantation. Provision of dragon fruit juice as an antioxidant from exposure to cigarette smoke, this is in line with previous research conducted by Ratih Mayasari which gives results that giving quercetin with a dose of $3.9 \mathrm{mg} / 20 \mathrm{gBB}$ and $7.8 \mathrm{mg} / 20 \mathrm{gBB}$ can prevent damage and fetal death caused giving tobacco water extract.

\section{Conclusion}

Cigarette smoke in pregnant mice can affect fetal weight and may also cause fetal morphological defects. Provision of red dragon fruit juice in pregnant mice exposed to cigarette smoke, can prevent the occurrence of disability and keep the fetus weight in accordance with the age of pregnancy. However, there was no effect on the number of fetuses that were born in negative groups, positive groups or treatment groups.

\section{Suggestion}

More research on microscopic effects of cigarette smoke, as well as a similar study using other types of plants.

\section{Thank-You Note}

Researchers would like to thank the Chairman of the Foundation, Rector, Chairman of LPPM, Dean of the Faculty of Health Sciences Ngudi Waluyo Ungaran University, and all colleagues-colleagues who have helped in the smooth running of this research.

\section{References}

1. The Lancet NCD Action Group and The NCD Alliance (2011) Health Policy : Priority action for the non communicable disease crisis, OECD.

2. GATS (2011) Global Adults Tobacco Survey Indonesia Report 2011. WHO Regional Organization, South East Asi.

3. Widowiak A, Dan Wiktor H (2009) Maternal Pasive Smoking and Neonatal Health. Departement of Obstetrics and Gynecology, Medical Universit 16(2): 309-12.

4. Yuliana (2009) Rokok Terhadap Defisiensi Asam Folat Selama Kehamilan, Diakses Dari.

5. Panjuantiningrum, Feranose (2016) Pengaruh Pemberian Buah Naga Merah (Hylocereus polyrhizuz) Terhadap Kadar Glukosa Darah Tikus Putih Yang Diinduksi Aloksan. (Tesis) Universitas Sebelas Maret, Indonesia.

6. Febrianti, Karina (2015) Pengaruh Pemberian Jus Buah Apel (Malus Sylvestris Mill) Varietas Rome Beauty Pada Mencit Hamil Yang Terpapar Asap Rokok. (Skripsi) Universitas Ngudi Waluyo, Indonesia.

7. Anggun Rindang Cempaka, Sanarto Santoso, Dan Laksmi Karunia Tanuwijaya (2014) Pengaruh Metode Pegolahan (Juicing dan Blending) Terhadap Kandungan Quercetin Berbagai Varietas Apel Lokal Dan Impor (Malus domestica). (Tesis) Indonesian Journal of Human Nutrition 1(1).

8. Rahmadina (2008) Pengaruh Pemberian Vitamin E terhadap Efek Teratogen dari Ekstrak Air Tembakau Rokok Kretek pada Mencit Putih. (Skripsi) UNAND, Padang, Indonesia.

\section{Your next submission with Juniper Publishers will reach you the below assets}

- Quality Editorial service

- Swift Peer Review

- Reprints availability

- E-prints Service

- Manuscript Podcast for convenient understanding

- Global attainment for your research

- Manuscript accessibility in different formats

( Pdf, E-pub, Full Text, Audio)

- Unceasing customer service

Track the below URL for one-step submission https://juniperpublishers.com/online-submission.php 